\title{
Attitudes of Palestinians EFL Students Towards the Use of Jigsaw Cooperative Learning Technique in Teaching Reading Comprehension
}

\author{
Enas A. A. Abuhamda ${ }^{1}$, Ramiaida Darmi2*, Hazlina Abdullah ${ }^{3}$, \\ enas@ raudah.usim.edu.my.ramiaida@usim.edu.my. hazlina@usim.edu.my.
}

\begin{abstract}
Reading comprehension plays a crucial role in developing the reading skills. Therefore, reading comprehension is one of the most significant skills of all the four linguistic abilities, towards better effectively communication in classroom. Subsequently, the English Language (EL) teachers should consider and find different teaching methods in their classrooms in order to improve the language abilities of their learners in the classrooms such as Jigsaw Cooperative Learning Technique (JCLT) through changing their methods, materials and overcoming the traditional way of teaching English language. The aim of the study was to investigate Palestinians EFL secondary students' attitudes towards the use of JCLT in teaching reading comprehension. In addition, the study adopted fully quantitative research design to collect data through the self-designed questionnaire survey that distributed randomly on a sample of 1094 Palestinians EFL secondary teachers in 2019-2020. The collected data were analyzed and treated statistically using SPSS.24. The results of the study showed that Palestinians EFL secondary students have positive attitudes towards using jigsaw cooperative learning technique as a tool in the EFL teaching. The recommendation andsuggestion for studies were suggested in light of the findings.
\end{abstract}

\section{Keywords:}

Cooperative learning, Jigsaw, Traditional methods, Reading comprehension, EFL, Palestine 


\section{Introduction}

Nowadays, English is the most widely used international language in the world. The Palestinian government has been motivated by the status of English as a global language to put great weight on the teaching and learning of English. Making improvements in the English curriculum, it subsequently made significant efforts to introduce the cooperative learning to improve communicative skill for the next generation, the Palestinian government has demanded that schools and teachers adopt cooperative learning techniques. On the other hand, by convincing the government that they are adopting cooperative learning, English language teachers are criticized for paying lip service when in fact they stick to their favorable the traditional methods" (Hu, 2002, Alakrash et al., 2021). In addition, English Language teachers need to prepare seventh graders communicatively to engage in normal ways to build or simulate culturally realistic circumstances that allow them to convey real meaning. Thus training them to choose from the many possibilities within the language confidently and quickly to express their intentions in natural interaction comprehensibly and acceptably by employing the most important skill "reading comprehension". It is the ability to read properly and fluently by utilizing the cooperative learning especially jigsaw technique (Alakrash\& Razak, 2020a). In this case, the researcher will implement the jigsaw cooperative learning technique in improving students' reading comprehension because it can be an effective and enjoyable technique for the seventh graders' interaction.

\section{Cooperative Learning (CL)}

Cooperative learning is an effective teaching method in which small teams use a range of learning activities to enhance their understanding of a target subject, each with students of different levels of skill (Abuhamda, 2020, Alakrash \& Razak, 2020b). In addition to learning what is taught, each member of a team is responsible for helping teammates learn, thereby fostering an environment of accomplishment. Students work through tasks before the mission is successfully understood and accomplished by all community members. It was pointed out that 'cooperative learning is a modern teaching method that drives weak students psychologically, leading to self-confidence and excellent target group performance.

- Teachers typically divide their classes into groups comprising at least (4-6) students, and it was stated. The jobs are distributed among the members of each party, such as a leader, a reader, a speaker, a researcher, and a writer. Students operate in groups and cohesive units-this helps all students to perform in their own way-they often work as hard as they can to support their partners.

- Cooperative learning facilitates student learning and increases their retention, and has been said.

- It also improves students' levels and focuses on poor ones. That is because it is changeable for groups and workers. This week, the leader could be the speaker or the reader next week.

- Academic performance enhancement techniques have been demonstrated, and cooperative learning contributes to greater learning motivation.

- It increases self-esteem and contributes to healthier social habits. It was also pointed out that Cooperative Learning facilitates language acquisition by providing understandable feedback in a positive and empowering atmosphere and in developmentally acceptable ways. 
- The investigator studied the issue using questionnaires and written tests to collect the data in the course of this report. The findings were examined and debated and suggestions were suggested to assist EFL students.

\section{Reading Comprehension ( $\mathrm{RC}$ )}

Understanding reading is one of the fundamental things that, because of the many issues it poses, attracts a lot of consideration from researchers and practitioners. Given the fact, that, since the last century, there has been a drastic shift toward a decline in illiteracy. There are also questions for those who do not read and write well enough (Krashen, 2004, Alakrash \&, Razak 2019). Even though understanding of reading is clearly described as comprehension. Educationalists accept that it is not a clear method and not convenient because of its sophistication. During the learning process, ESL / EFL students fail to create and derive sense and comprehend knowledge from texts they are expected to read (Grabe, 2011; Razak et al.2018).

In order to include a text for readers to understand. They have to "get involved" and incorporate their current expertise (Guthrie, 2004). In order to decipher uncertainty and understand the gist, text knowledge and the text meaning (Grabe, 2011). Risdianto (2012) as quoted in (Krashen, 2004) lists several more nuanced skills that experienced learners need to read. Therefore, because reading comprehension is an active and interactive process, there has been a strong call to expand students' opportunities for greater natural reading exposure (Yoon, 2002; Alakrash et al., 2020).

In the end, reading comprehension is a process of constructing meaning and obtaining data resulting from the interaction between a reader and the text (Lai, 2002). In today's information-based environment, reading comprehension is the most important indicator not only in the context of how cognitive techniques are used in a specific reading test. In addition, to assess the reading success of students with various reading platforms given the adjustments they have made that can influence their level of learning through the curriculum (Chen, Cheng et al. 2014). Comprehension of reading is a contentious subject with an extensive discussion on the suitability of reading media for understanding reading.

\section{The Importance of Cooperative Learning}

Johnson \& Johnson (1994) and Eachempati (2017) highlight five essential elements of effective CL; positive interdependence and individual responsibility encourage face-to -face engagement, small group skills and group processing. Cooperation promotes constructive interdependence, where all members of the community work together to achieve common objectives. Individuals therefore pursue results that are both advantageous to themselves and to the cooperation of the community members and encourage goal, interdependence that is positively connected in such a way that the likelihood of one individual achieving his / her goal is positively associated with the likelihood of others doing so. It also rewards interdependence, where the same reward is offered to all members of the community.

\section{Jigsaw Technique}

The jigsaw classroom was originally built in Austin, Texas by Elliot Aronson in 1971. Jigsaw is a cooperative learning strategy that involves everyone's cooperative effort to create the final product, because each member of a group has a piece of information required to complete a group task (Longman Dictionary of Language Teaching and Applied Linguistics, 1998) in the EFL classroom. Just as in a jigsaw puzzle, for the creation and full 
comprehension of the final product, each piece is necessary for each student's part. If the part of each student is important, then each student is necessary. That is precisely what makes this approach so successful. Jigsaw is said to be able to increase the learning of students because a) it is less risky for many students, b) it increases the amount of involvement of students in the classroom, c) it decreases the need for competition and d) it decreases the superiority of the teacher in the classroom (Longman Dictionary, 1998). Consequently, the jigsaw method will significantly minimize the reluctance of students to engage in classroom activities and help create an active environment based on learners. Studies have shown that cooperative efforts can only be assumed to be more efficient under some circumstances than competitive and individualistic efforts. Johnson, Johnson and Holubec (1994) put five concepts for jigsaw strategy forward:

\section{a. Positive interdependence}

The efforts of each group member are necessary and indispensable to the success of the group. Each member of the community has to make specific contributions to the common effort.

\section{b. Face-to-face promotive interaction}

Group members must explain how to solve problems orally, teach one's knowledge to others, search for comprehension, address concepts being learned and compare the current learning with the previous one.

\section{c. Individual and group accountability}

The group size should be kept small, since the bigger the group size, the greater the individual responsibility will be.

\section{d. Interpersonal skills}

For the performance of jigsaw learning in class, social skills are necessary. Leadership, decision-making, confidence building, communication, conflict-management skills and so on are social skills.

\section{e. Group processing}

Group members discuss how well their objectives are accomplished and how successful working relationships are maintained, explain what participant activities are beneficial and what are not, and determine what habits to continue or alter. Jigsaw learning makes it possible to expose students to materials and still bear a high degree of personal responsibility. This helps to develop teamwork and collaborative learning skills within all students and if the students study all of the material on their own, a depth of understanding is not possible. Finally, as learners are expected to disclose their own results in jigsaw learning to the home community, it very often shows the interpretation of a concept by a student as well as any misunderstandings.

\section{Traditional vs. Cooperative classrooms}

Traditional classrooms are characterized by teachercentered activities that typically include teacherstudent or student-initiated interactions (it should be noted that student-student interactions are minimal), based on methods such as the Grammar Translation Method or the Audio-Lingual Method. Students sit in separate desks or are put in pairs and the instructor is at the center of the classroom as a teaching process controller, performance assessor of the students, key source of information, assistance, input, motivation and encouragement. Traditional approaches see language learning as a passive method of memorizing the laws and artifacts of grammar and vocabulary in order to gain the ability to grasp and use the morphology and syntax of the foreign language concerned. Activities such as information recall and analysis, phrasal or sentence pattern practice, roleplay and translation are the subject of this form of learning (Vizental, 2007).

On the other hand, students are responsible for their own actions and learning while working together 
cooperatively, while the instructor monitors them and helps them work individually, giving them feedback; however, the teacher organizes and advises group work, promotes the tasks of communication and intervenes to teach collaborative skills (Bawn, 2007). Some learners can be too reliant on their instructor at first, and expect to be supported, corrected, and encouraged all the time. In this situation, the teacher may put them into collaborative small groups of less teacher-dependent students in order to increase their degree of independence, or pair them with students that are more independent. Therefore, if the interdependence of the students is seen as negative in conventional language learning, the learner being just a recipient or a performer, interdependence plays a positive role in cooperative learning, as the learner is involved and autonomous. In terms of materials, the instructor offers a full collection of materials for each student to collaboratively make them work together (Stone, 2007).

Cooperative learning refers to instructional methods involving small heterogeneous groups working together, typically towards a shared objective (Slavin, 1992) said. He (ibid) adds that this learning strategy requires improvements to both the nature of the task and the nature of the reward. The structure of the task relates to the ways in which the instructor or students set up tasks to contribute to learning for students, where a cooperative structure includes students working together to support each other. The reward system shifts from one individual to the general one, i.e. one student's success is positively linked to others' success.

The importance of engaging with students was highlighted by Johnson \& Johnson (1994), arguing that learning, enjoyment of school and other students, as well as self-esteem can be affected. However, only placing students in groups and asking them to work together for CL to work is not enough, as Johnson \& Johnson (1994) pointed out. In the end, how such groupings are organized will determine whether or not they will be more efficient than competitive or individualistic groupings. CL is important for creating inclusive classroom environments that meet the needs of all students because it takes heterogeneity into account, fostering peer support and link. Since most classrooms are heterogeneous, it only makes sense to use a teaching and learning approach that allows for this heterogeneity.

Increasing the amount of time and energy is dedicated to designing pedagogical methods that are suitable in heterogeneous classrooms as universities step closer to the objective of delivering education for all students inside inclusive classrooms. Cohen et.al, (2001) claimed that: Teachers need to organize the educational and social environment so that students build the information, skills and attitudes needed to communicate with perceived and real differences and disabilities in both perceived and real differences. Moreover, cooperative learning promotes mutual respect and learning among students of different talents and abilities, languages, racial and ethnic backgrounds Sapon-Shevin \& Duncan, (1992) noted that cooperative learning is successful in reading student prejudices and meeting the academic and social needs of students at risk of educational failure. When their unique strengths are recognised and unique needs are addressed, all students need to learn and work in the community. If teachers or students are dissatisfied with CL, it is often because, without a firm understanding of the underlying concepts, they have implemented a specific methodology and do not have adequate support to incorporate innovative, multi-level CL activities that allow students to engage with various goals and varying levels of support at different levels. 
Cooperative learning is a technique that has been part of the field of education for many years. It was built from the philosophy of constructivism that it has extended from its original design of only making students collaborate with a partner or small group. Via various research, the efficacy of cooperative learning has been demonstrated as an efficient method for increasing the understanding of students. Biggie and Stump (1999), Delmar Lorenzo (2005) and Low (2011). As well as Low (2011) and Eachempati (2017) found that by participating in cooperative learning activities, with well-planned scaffolding by their teachers, students could increase higherorder reading performance.

\section{The objective of the study}

To investigate Palestinians EFL secondary students' attitudes towards the use of JCLT in teaching reading comprehension.

\section{Methodology}

Quantitative method was used to achieve the main purpose of the study as well as to answer the research question. The researcher used one tool of the study namely questionnaire to fit the variables and the hypotheses of the study.

\section{Findings}

What are the attitudes of Palestinians EFL secondary students towards the use of JCLT in teaching reading comprehension?

In order to answer this question, the researchers calculated the means, standard deviations, percentages, levels, and ranks for students' attitudes towards utilizing the jigsaw cooperative learning technique as a tool for reading comprehension in English language. Table (1) shows the results.

Table (1) shows that the students' attitudes towards utilizing JCLT as a tool for reading comprehension in English language achieved a mean of (3.63) and a percentage of (72.6), which means that students' have positive attitudes towards utilizing JCLT as a technique for reading comprehension.

The findings of items (1-8) in table (1) showed that JCLT has positive impact on the secondary students' reading comprehension with respect to gender and location in Palestine. The total average for the third domain, which investigated the high impact on the students' English reading comprehension, was "71.4\%" with high impact that indicated more students use JCLT, the better their reading comprehension.

Additionally, the results showed that the majority of teachers agreed on the good attitudes of using JCLT as a study technique for reading comprehension with respect to gender and location. Secondary students confirmed that

Table (1)

Means, standard deviation, percentages and levels of students' attitudes towards utilizing the jigsaw cooperative learning technique as a tool for reading comprehension in English language. 
JCLT helps them to keep in communication with each other despite the geographical distances and gender "male or female."

The results to items (1-8) received a high impact degree, the majority of students"73.4\%, 71.4\%, 70.8\%, $71.8 \%$, $70.0 \%, 77.0 \%$ and $76.6 \%$."

\section{Conclusion}

Based on the findings of the study, the researcher arrived at the following conclusions: JCLT created with the goals of reducing conflict, enhancing positive educational outcomes, helping students to realize that they are crucial components of a whole and encouraging cooperation in a learning environment. This technique motivated students towards an independent practice of English language instead of direct directions. It was clear through teamwork activities and their asking for extra strategies during the lesson. JCLT developed collaborative learning among participants. This was clear because students learned through idea exchange and learned from their own mistakes as well as the mistakes of their partners. It provided great opportunities for low and intermediate achievers to get involved with high achievers and learn from them. Itis a very beneficial strategy for teaching EFL reading comprehension where participants in the experiment showed remarkable improvement in their reading and jigsaw cooperative learning technique helped participants build a sense of leadership because groups always have leaders.

\section{References}

[1] Abuhamda, E. A. A. (2020). The Effect of Jigsaw Cooperative Learning Strategy on Fourth Graders ' Achievement in Teaching EFL at Qalqilya City. Academic Journal of Business and Social Sciences, 4. https://www.researchgate.net/publication/343 404362.

[2] Aronson, E. (2008). Jigsaw classroom. Retrieved July 18, 2008 from http://www.jigsaw.org/.

[3] Aronson, E. (n.d). Overview of the Technique.
Jigsaw Classroom. Retrieved on November 29, 2014 form http://www.jigsaw.org/overview.htm.

[4] Bawn, S. (2007). The Effects of Cooperative Learning on Learning and Engagement. A Project for the Master in Teaching Degree. Faculty of the Evergreen State College.

[5] Berry, R. (2003). Creating Cooperative Classrooms. Education Digest, 69(2), 39-42.

\begin{tabular}{|l|l|l|l|l|l|}
\hline No. & Item & M & SD & P & Level \\
\hline 1 & $\begin{array}{l}\text { Students work well in their } \\
\text { groups through utilizing } \\
\text { JCLT. }\end{array}$ & 3.81 & 1.04 & 76.2 & High \\
\hline 2 & $\begin{array}{l}\text { Students prefer to write in } \\
\text { English by utilizing JCLT. }\end{array}$ & 3.74 & 1.05 & 74.8 & High \\
\hline 3 & $\begin{array}{l}\text { Students are motivated to } \\
\text { read comprehensively by } \\
\text { utilizing JCLT. }\end{array}$ & 3.71 & 1.02 & 74.2 & High \\
\hline 4 & $\begin{array}{l}\text { Students like to read utilizing } \\
\text { JCLT. }\end{array}$ & 3.68 & 1.03 & 73.6 & High \\
\hline 5 & $\begin{array}{l}\text { Students can read in English } \\
\text { properly through utilizing } \\
\text { JCLT. }\end{array}$ & 3.64 & 0.94 & 72.8 & High \\
\hline 6 & $\begin{array}{l}\text { Students read more if JCLT } \\
\text { is used as a supplementary } \\
\text { tool. }\end{array}$ & 3.63 & 1.01 & 72.6 & High \\
\hline 7 & $\begin{array}{l}\text { Utilizing JCLT encourages } \\
\text { students to be active, not shy. }\end{array}$ & 3.53 & 1.06 & 70.6 & High \\
\hline 8 & $\begin{array}{l}\text { Utilizing JCLT helps to } \\
\text { increase the students' } \\
\text { motivation for reading } \\
\text { comprehension. }\end{array}$ & 3.52 & 0.99 & 70.4 & High \\
\hline 9 & $\begin{array}{l}\text { Utilizing JCLT changes the } \\
\text { traditional way of teaching. }\end{array}$ & 3.45 & 1.04 & 69.0 & Moderate \\
\hline Total score of students' attitudes & $\mathbf{3 . 6 3}$ & $\mathbf{0 . 7 3}$ & $\mathbf{7 2 . 6}$ & High \\
\hline 6
\end{tabular}

[6] Chen, M. (2004). A study of the Effects of Cooperative Learning Strategies on Students' Achievement in English as a Foreign Language in a Taiwan college (China). Dissertation Abstracts International, A 65/01, p. 57.

[7] Cohen, E.G, Brody, C.M and Sapon-Shevin (2001) "Teaching Cooperative Learning. The challenge for teacher education. Cambridge University Press.

[8] Eachempati P, KS K, Ismail A, (2017), 'Cooperative learning through jigsaw classroom technique for designing cast partial dentures - a comparative study', MedEdPublish, 6, [2], 26, https://doi.org/10.15694/mep.2017.000088.

[9] Elsayed, M. M. S. (2018). The effectiveness of using 'learning together instruction' in improving reading comprehension among EFL undergraduates in the 
Kingdom of Saudi Arabia (Issue January). Univirsiti Sains Islam Malaysia.

[10] Grabe, W. \& Stoller, F. L. (2011). Teaching and researching reading. Harlow. England: Pearson Education.

[11] Grellet, F. (1986). Developing Reading Skills: A practical guide to reading comprehension exercises. Ernst Klett Sprachen.

[12] Hu, G. (2002). Potential Cultural Resistance to Pedagogical Imports: The Case of Communicative Language Teaching in China. Language, Culture, and Curriculum, 15(2), 93-105. doi: 10.1080/07908310208666636.

[13] Johnson, D. \& Johnson, R. (1994). Learning together and alone: Cooperative, competitive, and individualistic learning (4th Ed.). Boston: Allyn \& Bacon.

[14] Johnson, D. and Johnson, R. (1994). Positive interdependence: Key to effective cooperation. In R.Hertz - Lazarowitz and N.Miller, (Eds), Interaction in cooperative learning: The theoretical anatomy of group learning. (pp.174-199).Cambridge University Press.

[15] Krashen, S. D. (2004). The power of reading: Insights from the research: Insights from the research. ABC-CLIO.

[16] Lai, M. (2002). A study of cooperative learning in the EFL junior high classroom. National Chung Cheng University: Master's thesis.

[17] Lai, C. Y., \& Wu, Cheng-Chih (2006). Using handholds in a Jigsaw cooperative learning, students' goal preferences and perceptions of contextual factor in the classroom. Scandinavian Journal of psychology, 47 (1), 9-21.

[18] Risdianto, F. (2012). Effective and efficient reading. Solo: Rustam Publishing.

[19] Rojas-Drummond, S., Hernández, G., Vélez, M., \& Villagrán, G. (1998). Cooperative Learning and the Appropriation of Procedural Knowledge By Primary School Children. Learning and Instruction, 30(1), 37-61.

[20] Sapon-Shevin, and Duncan, J. (1992). Cooperative learning and inclusion. In J.S. Thousand, R.A. Villa, and AI. Nevin (Eds), Creativity and Collaborative Learning: A practical guide to empowering students and teachers. Baltimore: Paul H. Brooks Publishing Co.

[21] Slavin, R. (1992). Cooperative Learning: Theory, Research and Practice (2nd ed.).Boston: Allyn and Bacon.

[22] Stone, J. (2007). Cooperative Learning and English. Hawker Brownlow Education.

[23] Vizental, A. (2007). Strategies of Teaching and Testing English as a Foreign Language, Collegium, Polirom.

[24] Yoon, J. C. (2002). Effectiveness of sustained silent reading on reading attitude and reading comprehension of fourth-grade Korean students (Doctoral dissertation, USA).

[25] Yuhananik, Y. (2018). Using jigsaw model to improve reading comprehension of the ninth graders of SMPN 1 Karangploso. JOLTL: Indonesian Journal of Language Teaching and Linguistics, 3(1), 51-64.

[26] Alakrash, H., Razak, N, A. (2019). Motivation towards the application of ICT in English language learning among Arab EFL students. Journal of Advanced Research in Dynamical \& Control Systems, 11, 1197-1203.

[27] Alakrash, HM, Razak, NA, \& Bustan, ES (2020). The Effectiveness of Employing Telegram Application in Teaching Vocabulary: A Quasi Experimental Study. Multicultural Education, 6(1).

[28] Razak, N. A., Alakrash, H. M., \& Sahboun, Y. (2018). English Language Teachers' readiness For the Application of Technology Towards Fourth Industrial Revolution Demands. Asia-Pacific Journal of Information Technology and Multimedia, 7(2-2), 8998.

[29] Alakrash, H., Razak, N. A., \& Krish, P. (2021). Social Network Sites in Learning English; An Investigation on Attitudes, Digital Literacy and Usage. LINGUISTICA ANTVERPIENSIA, 26-43.

[30] Alakrash, H. M., \& Razak, N. A. (2020a). 
Redesigning the English Classroom Towards

Fourth Industrial Revolution, Are the Students Motivated?. The Asian ESP Journal, 16(4).

[31] Alakrash, H. M., \& Razak, N. A. (2020b). Towards the Education 4.0, Readiness Level of EFL Students in Utilising TechnologyEnhanced Classroom. International Journal of Innovation, Creativity and Change, Vol 13(10). 